\title{
Original TDAE Strategy Using Propargylic Chloride: Rapid Access to 1,4-Diarylbut-3-ynol Derivatives
}

\author{
Manon Roche, Thierry Terme and Patrice Vanelle * \\ Laboratoire de Pharmaco-Chimie Radicalaire, Faculté de Pharmacie, Institut de Chimie Radicalaire ICR, \\ UMR 7273, Aix-Marseille Univ, CNRS, 27 Boulevard Jean Moulin, 13385 Marseille Cedex 05, France \\ * Author to whom correspondence should be addressed; E-Mail: patrice.vanelle@univ-amu.fr; \\ Tel.: +33-491-835-573; Fax: +33-486-136-822.
}

Received: 12 November 2012; in revised form: 16 January 2013 / Accepted: 22 January 2013 / Published: 25 January 2013

\begin{abstract}
We report herein the first synthesis of propargylic alcohols using an organic reducing agent. Diarylbutynol derivatives are formed in moderate to good yields under mild conditions from the reaction of 1-(3-chloroprop-1-ynyl)-4-nitrobenzene with various aromatic aldehydes using tetrakis(dimethylamino)ethylene (TDAE) as reductant.
\end{abstract}

Keywords: TDAE; propargylic alcohol; organic reducing agent; aromatic aldehyde

\section{Introduction}

Propargylic alcohol derivatives have a major role to play in medicinal chemistry. They can act as intermediates for many complex organic molecules with valuable biological activities [1,2], for example efavirenz (Figure 1), an antiretroviral agent. Chalcone scaffolds (Figure 1), prepared from propargylic alcohols such as diaryl butynols, have been already used in the design and synthesis of molecules with anticancer activities. They are particularly important in the synthesis of novel antitubulin agents [3-5].

Different methods can be used to obtain propargylic alcohols. The most commonly used method is the addition of an acetylenic derivative to carbonyl compounds mediated by titanium, dialkyl zinc, etc. [2]. Tetrakis(dimethylamino)ethylene (TDAE) is an organic reducing agent [6,7] which reacts with haloalkyl derivatives to generate an anion under mild conditions via two sequential transfers of one electron. TDAE methodology has been widely explored in fluorine chemistry [8]. Since 2002, we have been applying this methodology in the nitrobenzylic series with various electrophiles such as aromatic 
aldehydes [9-12], ketones [9-12], $\alpha$-ketoesters [13-15], diethyl ketomalonate [13-15], $\alpha$-ketolactams [16], $\alpha$-diketones [17,18] and sulfonimine derivatives [19]. In this way, we have developed a program to explore the overall potential of TDAE-based chemistry in a medicinal setting [9,12,19-21]. To date, there has been no example of a TDAE-initiated reaction on alkyne derivatives in order to synthesize propargylic alcohols.

Figure 1. Example of molecules synthesized via propargylic alcohol derivatives.<smiles>C[C@]1(C#CC2CC2)NC(=O)Nc2ccc(Cl)cc21</smiles>

Efavirenz (EFV)

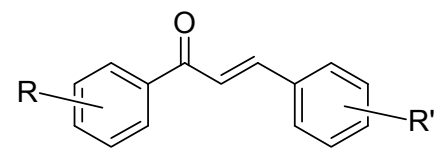

Chalcone derivatives

In a recent work, we explored the concept of Long-Distance- $\mathrm{S}_{\mathrm{RN}} 1$ (LD-S $\left.\mathrm{S}_{\mathrm{RN}} 1\right)$ on a propargylic chloride derivative such as 1-(3-chloroprop-1-ynyl)-4-nitrobenzene [22]. This latter compound also constitutes a potential substrate for the preparation of a propargylic anion using the TDAE strategy. In continuation of our research program directed towards the development of original synthetic methods in medicinal chemistry [23-28], we examined the use of TDAE methodology in the alkyne series. We report herein the synthesis of diarylbutynol derivatives from the reaction of 1-(3-chloroprop-1-ynyl)-4nitrobenzene with various aromatic aldehydes in the presence of TDAE.

\section{Results and Discussion}

The synthesis of 1-(3-chloroprop-1-ynyl)-4-nitrobenzene (1) was inspired by Chinchilla's work [29] on Sonogashira reactions and was performed as previously described (Scheme 1) [22].

Scheme 1. Synthesis of chloride 1.
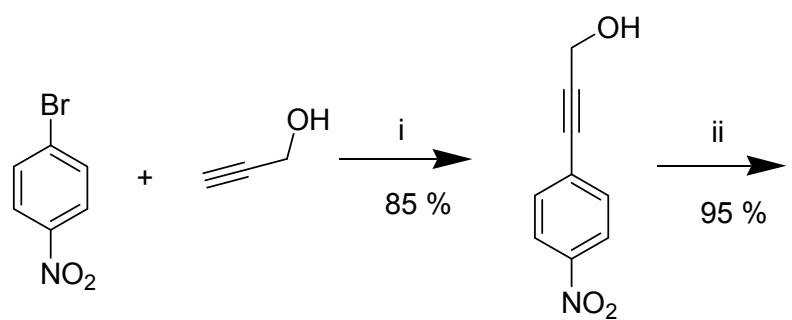<smiles>O=[N+]([O-])c1ccc(C#CCCl)cc1</smiles>

Reagents and Conditions: (i) $\mathrm{Pd}\left(\mathrm{PPh}_{3}\right)_{4} 0.5 \%$, Cul 1\%, pyrrolidine 1.5 equiv., $\mathrm{H}_{2} \mathrm{O} / \mathrm{THF}, 70{ }^{\circ} \mathrm{C}, 3 \mathrm{~h}$; (ii) $\mathrm{SOCl}_{2} 3$ equiv., $\mathrm{CH}_{2} \mathrm{Cl}_{2}: 0{ }^{\circ} \mathrm{C} ; 40{ }^{\circ} \mathrm{C}, 4 \mathrm{~h}$.

In order to evaluate the reducibility of the substrate 1, we treated it under classical TDAE conditions [9] but without electrophile. This reaction led to the reduction product 2 (Scheme 2) in $90 \%$ yield, and confirmed the reducibility of 1 by TDAE. 
Scheme 2. TDAE-initiated reactivity of chloride 1.

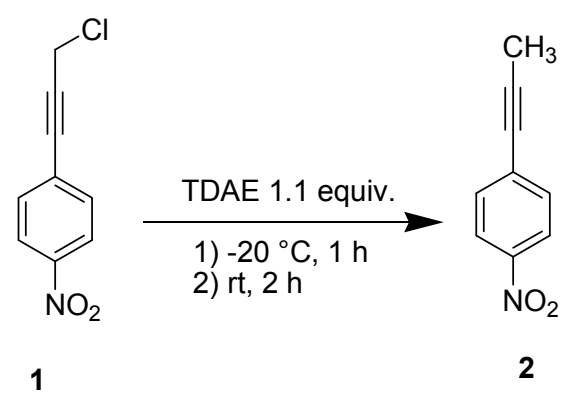

We therefore proceeded to explore whether of a propargylic anion could be formed using TDAE with nucleophilic addition to a carbonyl derivative as electrophile. The first attempt was made under classical TDAE conditions [9]. The reaction of the 1-(3-chloroprop-1-ynyl)-4-nitrobenzene (1) with three equiv. of $p$-chlorobenzaldehyde (3a) in the presence of 1.1 equiv. of TDAE at $-20{ }^{\circ} \mathrm{C}$ for $1 \mathrm{~h}$ (stage 1) followed by $2 \mathrm{~h}$ at $\mathrm{rt}$ (stage 2) yielded diarylbutynol 4a in $40 \%$ yield (Entry 1, Table 1). Aromatic aldehydes were chosen as electrophiles based on our previous TDAE studies (more reactive electrophiles for the TDAE strategy) and with the view to obtaining chalcone precursors. In order to optimize this reaction, we changed some parameters (solvent, amount of aldehyde, solvent volume, temperature during stage 1 or stage 2 and reaction time of stage 2), as shown in Table 1 and Scheme 3. During this study, the formation of an oxirane derivative 5a was observed as by-product when we used 10 or $20 \mathrm{~mL}$ of DMF (Entries 4 and 7).

Scheme 3. TDAE-initiated reactivity of chloride $\mathbf{1}$ and $p$-chlorobenzaldehyde $\mathbf{3 a}$.

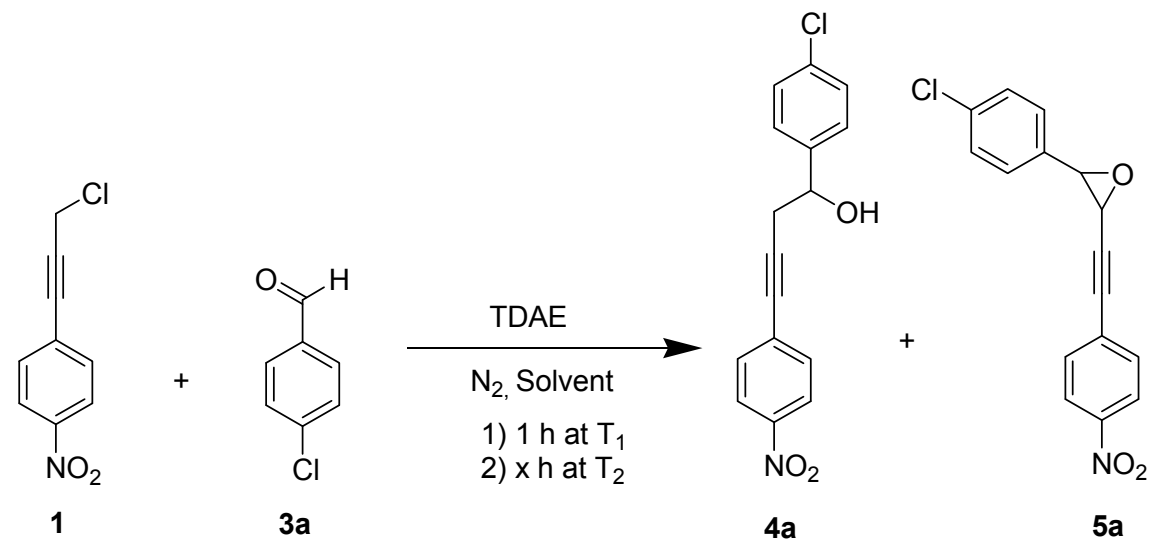

Modification of certain parameters (solvent, aldehyde amount and reaction time) did not lead to any increase in yield of $4 \mathbf{a}$. Reducing the temperature of stage $1\left(-20^{\circ} \mathrm{C}\right.$ to $-50{ }^{\circ} \mathrm{C}$; Entry 8) did not change diarylbutynol yields, but did improve the treatment of the reaction. Recently, we showed that the temperature of stage 2 affects TDAE reactivity in the $o$-nitrobenzylic series [30]. Thus, in Entry 9 the reaction was stirred under $60{ }^{\circ} \mathrm{C}$ for $2 \mathrm{~h}$ in stage 2 and diarylbutynol $4 \mathrm{a}$ was obtained in $65 \%$ yield. As observed in benzylic [9,13], heterocyclic [14] and quinonic [12] series, the formation of this product may be explained by an ionic addition of carbanion, formed by action of TDAE with 1-(3-chloroprop-1-ynyl)-4-nitrobenzene, on the carbonyl group of the benzaldehyde. 
Table 1. Reactivity of 1-(3-chloroprop-1-ynyl)-4-nitrobenzene 1 with $p$-chlorobenzaldehyde 3a.

\begin{tabular}{|c|c|c|c|c|c|c|c|c|}
\hline \multirow{2}{*}{ Entry ${ }^{a}$} & \multirow{2}{*}{$\begin{array}{c}\text { Equiv. of } \\
3 \mathrm{a}\end{array}$} & \multirow{2}{*}{ Solvent } & \multirow{2}{*}{$T_{1}{ }^{d}$} & \multirow{2}{*}{$\begin{array}{c}\text { Time of reaction } \\
\text { (stage 2) }\end{array}$} & \multirow{2}{*}{$\mathbf{T}_{2}{ }^{\mathrm{e}}$} & \multicolumn{3}{|c|}{ (\%) Yield ${ }^{c}$} \\
\hline & & & & & & 1 & $4 a$ & $5 a$ \\
\hline 1 & 3 & DMF, 4 mL & $-20^{\circ} \mathrm{C}$ & $2 \mathrm{~h}$ & $\mathrm{rt}$ & - & 40 & - \\
\hline $2^{b}$ & 3 & THF, 4 mL & $-20^{\circ} \mathrm{C}$ & $2 \mathrm{~h}$ & $\mathrm{rt}$ & - & - & - \\
\hline 3 & 3 & $\mathrm{MeCN}, 4 \mathrm{~mL}$ & $-20^{\circ} \mathrm{C}$ & $2 \mathrm{~h}$ & $\mathrm{rt}$ & 85 & - & - \\
\hline 4 & 3 & DMF, 4 mL & $-20^{\circ} \mathrm{C}$ & $6 \mathrm{~h}$ & $\mathrm{rt}$ & - & 6 & traces \\
\hline 5 & 1 & DMF, 4 mL & $-20^{\circ} \mathrm{C}$ & $2 \mathrm{~h}$ & $\mathrm{rt}$ & - & 12 & - \\
\hline 6 & 4 & DMF, 4 mL & $-20^{\circ} \mathrm{C}$ & $2 \mathrm{~h}$ & $\mathrm{rt}$ & - & 20 & - \\
\hline 7 & 3 & $\mathrm{DMF}, 10 \mathrm{~mL}$ & $-20{ }^{\circ} \mathrm{C}$ & $2 \mathrm{~h}$ & $\mathrm{rt}$ & - & 38 & 20 \\
\hline 8 & 3 & DMF, 4 mL & $-50{ }^{\circ} \mathrm{C}$ & $2 \mathrm{~h}$ & $\mathrm{rt}$ & - & 45 & - \\
\hline 9 & 3 & DMF, 4 mL & $-50{ }^{\circ} \mathrm{C}$ & $2 \mathrm{~h}$ & $60^{\circ} \mathrm{C}$ & - & 65 & - \\
\hline 10 & 3 & $\mathrm{DMF}, 10 \mathrm{~mL}$ & $-50^{\circ} \mathrm{C}$ & $2 \mathrm{~h}$ & $\mathrm{rt}$ & - & 25 & 35 \\
\hline 11 & 3 & $\mathrm{DMF}, 20 \mathrm{~mL}$ & $-20^{\circ} \mathrm{C}$ & $2 \mathrm{~h}$ & $\mathrm{rt}$ & - & 30 & traces \\
\hline 12 & 3 & $\mathrm{DMF}, 20 \mathrm{~mL}$ & $-50^{\circ} \mathrm{C}$ & $2 \mathrm{~h}$ & $\mathrm{rt}$ & - & 38 & 25 \\
\hline 13 & 3 & $\mathrm{DMF}, 20 \mathrm{~mL}$ & $-50{ }^{\circ} \mathrm{C}$ & $6 \mathrm{~h}$ & $\mathrm{rt}$ & - & 25 & 25 \\
\hline
\end{tabular}

${ }^{a}$ All reactions were performed using strictly anhydrous solvent, with 1 equiv. $(0.5 \mathrm{mmol})$ of chloride $\mathbf{1}$, 1.1 equiv. of TDAE and $1 \mathrm{~h}$ for stage $1 ;{ }^{b}$ Only degradation products were observed; ${ }^{\mathrm{c}}$ All yields refer to the chromatographically isolated products and are relative to chloride $1 ;{ }^{d} \mathrm{~T}_{1}$ : Temperature stage 1 ; ${ }^{\mathrm{e}} \mathrm{T}_{2}$ : Temperature stage 2 .

Otherwise, the reaction led to oxirane $\mathbf{5 a}$ as by-product in entries 4 and 7 . Using the TDAE methodology, the formation of oxirane derivatives with gem-dihalomethyl derivatives has already been described [11], but not with monohalogenated compounds. To elucidate the pathway for the formation of this product, certain parameters were modified (Table 1, Entries 10-13). In these assays, the best yield (35\%) of product 5a was obtained for Entry 10 , in the presence of 1.1 equiv. of TDAE at $-50{ }^{\circ} \mathrm{C}$ for $1 \mathrm{~h}$ (stage 1) followed by $2 \mathrm{~h}$ at $\mathrm{rt}$ (stage 2), in $10 \mathrm{~mL}$ of extra-dry DMF. The reaction with the highest volume of DMF (Entry 12) did not lead to an increased yield of product 5a. All this suggests the formation of oxirane 5a in dilute solutions by an intramolecular rearrangement via the propargylic/allenic equilibrium (Scheme 4). ${ }^{1} \mathrm{H}-\mathrm{NMR}$ spectral studies identify oxirane as cis-isomer by their coupling constant. Two distinct doublets appeared in the region at 3.97-4.25 ppm with a coupling constant $J=3.8 \mathrm{~Hz}$, in agreement with the literature [31,32].

Scheme 4. Hypothetical pathway for the formation of oxirane derivative.
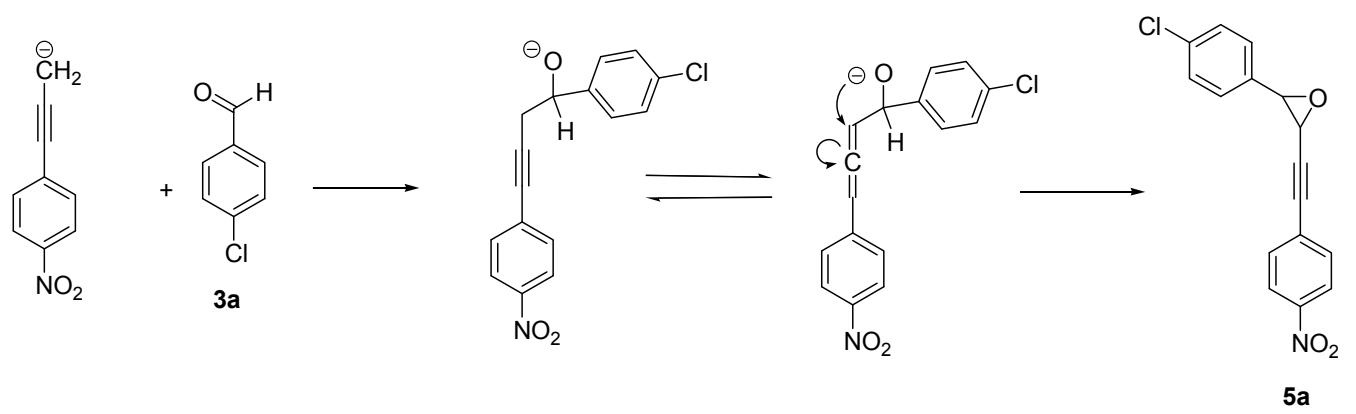

In order to generalize and to confirm this new and original methodology of synthesizing diarylbutynol derivatives, we extended this study to other aromatic aldehydes using an optimized 
protocol. The reaction of 1-(3-chloroprop-1-ynyl)-4-nitrobenzene $\mathbf{1}$ with electrophiles $\mathbf{3 a}-\mathbf{g}$ in the presence of TDAE, under the conditions of Entry 9 (Table 1), led to the corresponding diarylbutynol derivatives $4 \mathbf{a}-\mathbf{g}$ in moderate to good yields (30\% to 65\%) as shown in Table 2 and Scheme 5.

Scheme 5. Extension of the reactivity of chloride 1 with various benzaldehydes $\mathbf{3 a}-\mathbf{g}$.

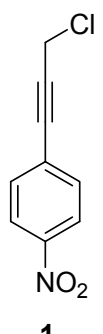

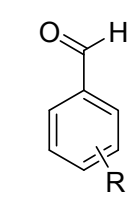

3a-g

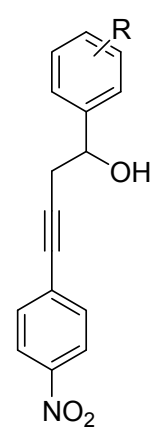

$4 a-g$

Table 2. Reaction of chloride $\mathbf{1}$ with various aromatic aldehydes ${ }^{\mathrm{a}}$.

\begin{tabular}{llcc}
\hline Aromatic aldehyde & $\mathbf{R}$ & & $\mathbf{( \% )}$ Yield $^{\mathbf{b}}$ \\
\hline 4-Chlorobenzaldehyde & $4-\mathrm{Cl}$ & $\mathbf{4 a}$ & 65 \\
4-Nitrobenzaldehyde & $4-\mathrm{NO}_{2}$ & $\mathbf{4 b}$ & 57 \\
4-Fluorobenzaldehyde & $4-\mathrm{F}$ & $\mathbf{4 c}$ & $34^{\mathrm{c}}$ \\
4-Tolualdehyde & $4-\mathrm{CH}_{3}$ & $\mathbf{4 d}$ & traces \\
4-Trifluoromethylbenzaldehyde & $4-\mathrm{CF}_{3}$ & $\mathbf{4 e}$ & 51 \\
2-Nitro-4,5-dimethoxybenzaldehyde & $2-\mathrm{NO}_{2}-4,5-\left(\mathrm{OCH}_{3}\right)_{2}$ & $\mathbf{4 f}$ & 32 \\
Benzaldehyde & $\mathrm{H}$ & $\mathbf{4 g}$ & $30^{\mathrm{d}}$ \\
\hline
\end{tabular}

${ }^{\mathrm{a}}$ All reactions are performed using 3 equiv. of aromatic aldehyde $\mathbf{3 a}-\mathbf{g}, 1$ equiv. $(0.5 \mathrm{mmol})$ of chloride $\mathbf{1}$, 1.1 equiv. of TDAE in $4 \mathrm{~mL}$ of strictly anhydrous DMF, stirred at $-50{ }^{\circ} \mathrm{C}$ for $1 \mathrm{~h}$ and then warmed at $60{ }^{\circ} \mathrm{C}$ for $2 \mathrm{~h} ;{ }^{\mathrm{b}}$ All yields refer to the chromatographically isolated products and are relative to chloride $\mathbf{1}$; ${ }^{\mathrm{c}}$ We observed the formation of reduction product $\mathbf{2}$ in $25 \%$ yield; ${ }^{\mathrm{d}} \mathrm{We}$ observed the formation of reduction product 2 in $20 \%$ yield.

As already described in the nitrobenzylic [9,10] or quinonic [12] series, aromatic aldehydes with an electron withdrawing group are more reactive than aromatic aldehydes substituted by an electrondonor group such as methyl (compound 3d). The formation of the reduction product $\mathbf{2}$, isolated as byproduct with 4-tolualdehyde (3d) or benzaldehyde (3g), has already been detected in our previous studies when the substrate is more reducible and the electrophile is less reactive $[15,33,34]$.

\section{Experimental}

\subsection{General}

Elemental analysis or mass spectrometry were performed by the Spectropole Centre, Aix Marseille University (Marseille, France) The ${ }^{1} \mathrm{H}$ - and ${ }^{13} \mathrm{C}$-NMR spectra were determined on a Bruker AC 200 spectrometer operating at 200 and $50 \mathrm{MHz}$, respectively. The ${ }^{1} \mathrm{H}-\mathrm{NMR}$ chemical shifts are reported as parts per million downfield from tetramethylsilane $\left(\mathrm{Me}_{4} \mathrm{Si}\right)$, the ${ }^{13} \mathrm{C}$ chemical shifts were referenced to the solvent peaks $\left[\mathrm{CDCl}_{3}\right.$ : $76.9 \mathrm{ppm}$ and $\left(\mathrm{CD}_{3}\right)_{2} \mathrm{CO}: 206.3 \mathrm{ppm}$ and $\left.29.8 \mathrm{ppm}\right]$. Absorptions are 
reported with the following notations: $\mathrm{s}$, singlet, $\mathrm{d}$, doublet, $\mathrm{t}$, triplet, $\mathrm{q}$, quartet, $\mathrm{m}$, a more complex multiplet or overlapping multiplets. The following absorbents were used for column chromatography: silica gel 60 (Merck, particle size 0.0063-0.200, 70-230 mesh ASTM). TLC was performed on $5 \mathrm{~cm} \times 10 \mathrm{~cm}$ aluminium plates coated with silica gel 60 F-254 (Merck) with an appropriate eluent.

\subsection{General Procedure for TDAE Reaction with Aromatic Aldehydes}

All materials were dried for one day at $120^{\circ} \mathrm{C}$. Into a two-necked flask equipped with a silica-gel drying tube and a nitrogen inlet, was added, under nitrogen at $-50{ }^{\circ} \mathrm{C}$, an anhydrous DMF solution $(4 \mathrm{~mL})$ of 1 ( $0.1 \mathrm{~g}, 0.51 \mathrm{mmol})$ and aldehyde $\mathbf{3 a}-\mathbf{g}$ (1.53 mmol, 3 equiv.). The solution was stirred and maintained at this temperature for $30 \mathrm{~min}$ and then the TDAE $(0.127 \mathrm{~mL}, 0.55 \mathrm{mmol}, 1.1 \mathrm{equiv}$. $)$ was added dropwise (via a syringe). A green color immediately developed. The solution was vigorously stirred at $-50{ }^{\circ} \mathrm{C}$ for $1 \mathrm{~h}$ and then warmed at $60{ }^{\circ} \mathrm{C}$ for $2 \mathrm{~h}$. After this time TLC analysis (dichloromethane) clearly showed that $\mathbf{1}$ was totally consumed. The brown turbid solution was hydrolyzed with $\mathrm{H}_{2} \mathrm{O}(5 \mathrm{~mL})$. The aqueous solution was extracted with dichloromethane $(3 \times 10 \mathrm{~mL})$, the combined organic layers washed with brine $(3 \times 10 \mathrm{~mL})$ and dried over $\mathrm{MgSO}_{4}$. Evaporation of the solvent left the crude product as a viscous orange liquid. Purification by silica gel chromatography (eluent dichloromethane) gave the corresponding diarylbutynols $\mathbf{4 a - g}$.

1-(4-Chlorophenyl)-4-(4-nitrophenyl)but-3-yn-1-ol (4a). A yellow oil (98 mg, 65\%). ${ }^{1} \mathrm{H}-\mathrm{NMR}$ $\left(\mathrm{CDCl}_{3}\right): \delta 8.16(2 \mathrm{H}, \mathrm{d}, J=8.8 \mathrm{~Hz}), 7.50(2 \mathrm{H}, \mathrm{d}, J=8.8 \mathrm{~Hz}), 7.37(4 \mathrm{H}, \mathrm{s}), 4.98(1 \mathrm{H}, \mathrm{t}, J=6.2 \mathrm{~Hz})$, $2.90(2 \mathrm{H}, \mathrm{d}, J=6.2 \mathrm{~Hz}) .{ }^{13} \mathrm{C}-\mathrm{NMR}\left(\mathrm{CDCl}_{3}\right): \delta 146.9(\mathrm{C}), 140.9(\mathrm{C}), 133.9(\mathrm{C}), 132.4(2 \mathrm{CH}), 130.1$ (C), $128.7(2 \mathrm{CH}), 127.2(2 \mathrm{CH}), 123.5(2 \mathrm{CH}), 91.6(\mathrm{C}), 81.7(\mathrm{C}), 71.8(\mathrm{CH}), 30.5\left(\mathrm{CH}_{2}\right)$. HRMS calcd. for $\mathrm{C}_{16} \mathrm{H}_{12} \mathrm{ClNO}_{3}:[\mathrm{M}+\mathrm{H}]^{+}=302.0578$, found: $[\mathrm{M}+\mathrm{H}]^{+}=302.0577$.

1,4-Bis(4-nitrophenyl)but-3-yn-1-ol (4b). A yellow solid (90 mg, 57\%). ${ }^{1} \mathrm{H}-\mathrm{NMR}\left[\left(\mathrm{CD}_{3}\right)_{2} \mathrm{CO}\right]: \delta 8.25$ $(2 \mathrm{H}, \mathrm{d}, J=8.6 \mathrm{~Hz}), 8.19(2 \mathrm{H}, \mathrm{d}, J=8.6 \mathrm{~Hz}), 7.83(2 \mathrm{H}, \mathrm{d}, J=8.6 \mathrm{~Hz}), 7.59(2 \mathrm{H}, \mathrm{d}, J=8.6 \mathrm{~Hz}), 5.19$ $(1 \mathrm{H}, \mathrm{m}), 2.97(2 \mathrm{H}, \mathrm{d}, J=5.5 \mathrm{~Hz}) .{ }^{13} \mathrm{C}-\mathrm{NMR}\left[\left(\mathrm{CD}_{3}\right)_{2} \mathrm{CO}\right]: \delta 152.5(\mathrm{C}), 148.3(\mathrm{C}), 147.9(\mathrm{C}), 133.2$ $(2 \mathrm{CH}), 131.3(\mathrm{C}), 128.1(2 \mathrm{CH}), 124.4(2 \mathrm{CH}), 124.0(2 \mathrm{CH}), 93.2(\mathrm{C}), 82.0(\mathrm{C}), 71.7(\mathrm{CH}), 30.6\left(\mathrm{CH}_{2}\right)$. HRMS calcd. for $\mathrm{C}_{16} \mathrm{H}_{12} \mathrm{~N}_{2} \mathrm{O}_{5}:[\mathrm{M}+\mathrm{Na}]^{+}=335.0638$, found: $[\mathrm{M}+\mathrm{Na}]^{+}=335.0638$.

1-(4-Fluorophenyl)-4-(4-nitrophenyl)but-3-yn-1-ol (4c). A yellow oil (50 mg, 34\%). ${ }^{1} \mathrm{H}-\mathrm{NMR}$ $\left(\mathrm{CDCl}_{3}\right): \delta 8.15(2 \mathrm{H}, \mathrm{d}, J=8.8 \mathrm{~Hz}), 7.5(2 \mathrm{H}, \mathrm{d}, J=8.8 \mathrm{~Hz}), 7.40(2 \mathrm{H}, \mathrm{m}), 7.08(2 \mathrm{H}, \mathrm{m}), 4.98(1 \mathrm{H}, \mathrm{t}$, $J=6.3 \mathrm{~Hz}), 2.90(2 \mathrm{H}, \mathrm{d}, J=6.3 \mathrm{~Hz}) .{ }^{13} \mathrm{C}-\mathrm{NMR}\left(\mathrm{CDCl}_{3}\right): \delta 162.3(1 \mathrm{C}, \mathrm{d}, J=246.6 \mathrm{~Hz}), 147.0(\mathrm{C})$, $138.2(\mathrm{C}), 132.4(2 \mathrm{CH}), 130.2(\mathrm{C}), 127.6(2 \mathrm{CH}, \mathrm{d}, J=8.4 \mathrm{~Hz}), 123.6(2 \mathrm{CH}), 115.4(2 \mathrm{CH}, \mathrm{d}, J=21.6 \mathrm{~Hz})$, $91.6(\mathrm{C}), 81.7(\mathrm{C}), 71.9(\mathrm{CH}), 30.6\left(\mathrm{CH}_{2}\right)$. HRMS calcd. for $\mathrm{C}_{16} \mathrm{H}_{12} \mathrm{FNO}_{3}$ : $[\mathrm{M}+\mathrm{Na}]^{+}=308.0693$, found: $[\mathrm{M}+\mathrm{Na}]^{+}=308.0692$.

4-(4-Nitrophenyl)-1-p-tolylbut-3-yn-1-ol (4d). Traces. ${ }^{1} \mathrm{H}-\mathrm{NMR}\left(\mathrm{CDCl}_{3}\right): \delta 8.29(2 \mathrm{H}, \mathrm{d}, J=8.8 \mathrm{~Hz})$, $7.40(2 \mathrm{H}, \mathrm{m}), 7.10(4 \mathrm{H}, \mathrm{m}), 7.08(2 \mathrm{H}, \mathrm{m}), 4.98(1 \mathrm{H}, \mathrm{m}), 2.41(3 \mathrm{H}, \mathrm{s})$.

4-(4-Nitrophenyl)-1-[4-(trifluoromethyl)phenyl]but-3-yn-1-ol (4e). A yellow oil (87 mg, 51\%). ${ }^{1} \mathrm{H}-\mathrm{NMR}\left(\mathrm{CDCl}_{3}\right): \delta 8.17(2 \mathrm{H}, \mathrm{d}, J=8.8 \mathrm{~Hz}), 7.60(4 \mathrm{H}, \mathrm{m}), 7.50(2 \mathrm{H}, \mathrm{d}, J=8.8 \mathrm{~Hz}), 5.06(1 \mathrm{H}, \mathrm{m})$, $2.93(2 \mathrm{H}, \mathrm{d}, J=6.3 \mathrm{~Hz}), 2.42(1 \mathrm{H}, \mathrm{bs}, \mathrm{OH}) .{ }^{13} \mathrm{C}-\mathrm{NMR}\left(\mathrm{CDCl}_{3}\right): \delta 147.0(\mathrm{C}), 146.3(\mathrm{C}), 132.4(2 \mathrm{CH})$, 
$130.3(1 \mathrm{C}, \mathrm{q}, J=32.3 \mathrm{~Hz}), 129.9(\mathrm{C}), 126.1(2 \mathrm{CH}), 127.5$ (2CH, q, $J=3.6 \mathrm{~Hz}), 124.0$ (C, q, $J=272.3 \mathrm{~Hz})$, $123.6(2 \mathrm{CH}), 91.2(\mathrm{C}), 81.9(\mathrm{C}), 71.9(\mathrm{CH}), 30.5\left(\mathrm{CH}_{2}\right)$. HRMS calcd. for $\mathrm{C}_{17} \mathrm{H}_{12} \mathrm{~F}_{3} \mathrm{NO}_{3}$ : $[\mathrm{M}+\mathrm{Na}]^{+}=358.0661$, found: $[\mathrm{M}+\mathrm{Na}]^{+}=358.0661$.

1-(4,5-Dimethoxy-2-nitrophenyl)-4-(4-nitrophenyl)but-3-yn-1-ol (4f). A brown oil (60 mg, 32\%). ${ }^{1} \mathrm{H}-\mathrm{NMR}\left(\mathrm{CDCl}_{3}\right): \delta 8.15(2 \mathrm{H}, \mathrm{d}, J=8.8 \mathrm{~Hz}), 7.62(1 \mathrm{H}, \mathrm{s}), 7.51(2 \mathrm{H}, \mathrm{d}, J=8.8 \mathrm{~Hz}), 7.40(1 \mathrm{H}, \mathrm{s}), 5.76$ $(1 \mathrm{H}, \mathrm{dd}, J=6.9$ and $4.3 \mathrm{~Hz}), 3.96(6 \mathrm{H}, \mathrm{s}), 3.15(1 \mathrm{H}, \mathrm{dd}, J=16.9$ and $4.3 \mathrm{~Hz}), 3.05(1 \mathrm{H}, \mathrm{dd}, J=16.9$ and $6.9 \mathrm{~Hz}) .{ }^{13} \mathrm{C}-\mathrm{NMR}\left(\mathrm{CDCl}_{3}\right): \delta 153.7(\mathrm{C}), 148.2(\mathrm{C}), 146.9(\mathrm{C}), 139.7(\mathrm{C}), 133.4(\mathrm{C}), 132.4(2 \mathrm{CH})$, $130.2(\mathrm{C}), 123.6(2 \mathrm{CH}), 109.2(\mathrm{CH}), 107.8(\mathrm{CH}), 91.7(\mathrm{C}), 81.8(\mathrm{C}), 67.7(\mathrm{CH}), 56.4\left(2 \mathrm{OCH}_{3}\right), 29.7$ $\left(\mathrm{CH}_{2}\right)$. HRMS calcd. for $\mathrm{C}_{18} \mathrm{H}_{16} \mathrm{~N}_{2} \mathrm{O}_{7}:[\mathrm{M}+\mathrm{Na}]^{+}=395.0850$, found: $[\mathrm{M}+\mathrm{Na}]^{+}=395.0849$.

4-(4-Nitrophenyl)-1-phenylbut-3-yn-1-ol (4g). A yellow oil (41 mg, 30\%). ${ }^{1} \mathrm{H}-\mathrm{NMR}\left(\mathrm{CDCl}_{3}\right): \delta 8.15$ $(2 \mathrm{H}, \mathrm{d}, J=8.8 \mathrm{~Hz}), 7.50(2 \mathrm{H}, \mathrm{d}, J=8.8 \mathrm{~Hz}), 7.40(5 \mathrm{H}, \mathrm{m}), 5.00(1 \mathrm{H}, \mathrm{t}, J=6.3 \mathrm{~Hz}), 2.92(2 \mathrm{H}, \mathrm{d}$, $J=6.3 \mathrm{~Hz}) .{ }^{13} \mathrm{C}-\mathrm{NMR}\left(\mathrm{CDCl}_{3}\right): \delta 146.9(\mathrm{C}), 142.5(\mathrm{C}), 132.4(2 \mathrm{CH}), 130.3(\mathrm{C}), 128.6(2 \mathrm{CH}), 128.2$ $(\mathrm{CH}), 125.8(2 \mathrm{CH}), 123.5(2 \mathrm{CH}), 92.2(\mathrm{C}), 81.5(\mathrm{C}), 72.6(\mathrm{CH}), 30.5\left(\mathrm{CH}_{2}\right)$. HRMS calcd. for $\mathrm{C}_{16} \mathrm{H}_{13} \mathrm{NO}_{3}:\left[\mathrm{M}+\mathrm{NH}_{4}\right]^{+}=285.1234$, found: $\left[\mathrm{M}+\mathrm{NH}_{4}\right]^{+}=285.1238$.

Compound 5a was isolated in 35\% yield according to the general procedure cited above, but using $10 \mathrm{~mL}$ of DMF as solvent, rt for stage 2 (Table 1, Entry 10) and purification by silica gel chromatography (dichloromethane/petroleum ether 7/3).

2-(4-Chlorophenyl)-3-[(4-nitrophenyl)ethynyl]oxirane (cis isomer) (5a). A yellow oil (57 mg, 35\%). ${ }^{1} \mathrm{H}-\mathrm{NMR}\left(\mathrm{CDCl}_{3}\right): \delta 8.14(2 \mathrm{H}, \mathrm{d}, J=8.8 \mathrm{~Hz}), 7.40(2 \mathrm{H}, \mathrm{d}, J=8.8 \mathrm{~Hz}), 7.39(4 \mathrm{H}, \mathrm{s}), 4.24(1 \mathrm{H}, \mathrm{d}$, $J=3.8 \mathrm{~Hz}), 3.98(1 \mathrm{H}, \mathrm{d}, J=3.8 \mathrm{~Hz}) .{ }^{13} \mathrm{C}-\mathrm{NMR}\left(\mathrm{CDCl}_{3}\right): \delta 134.6(\mathrm{C}), 132.6(2 \mathrm{CH}), 132.5(\mathrm{C}), 128.5$ (C), $128.2(4 \mathrm{CH}), 123.6(2 \mathrm{CH}), 88.6(\mathrm{C}), 84.1(\mathrm{C}), 58.7(\mathrm{CH}), 48.4(\mathrm{CH}) . \mathrm{C}-\mathrm{NO}_{2}$ was not observed under these experimental conditions. HRMS calcd. for $\mathrm{C}_{16} \mathrm{H}_{10} \mathrm{ClNO}_{3}$ : $\left[\mathrm{M}+\mathrm{NH}_{4}\right]^{+}=317.0687$, found: $\left[\mathrm{M}+\mathrm{NH}_{4}\right]^{+}=317.0687$.

\section{Conclusions}

This study is the first to report on the use of the TDAE methodology in an alkyne series. The reaction of 1-(3-chloroprop-1-ynyl)-4-nitrobenzene (1) with aromatic aldehydes led to the corresponding alcohols $\mathbf{4 a}-\mathbf{g}$ in moderate to good yields. We present here the first example of the formation of a propargylic carbanion via the TDAE methodology. This is an original and mild method to synthesize diarylbutynol derivatives as chalcone precursors with potential for pharmacological use as anticancer agents.

\section{Acknowledgments}

This work was supported by the Centre National de la Recherche Scientifique. We express our thanks to Vincent Remusat for recording the ${ }^{1} \mathrm{H}$ and ${ }^{13} \mathrm{C}$-NMR spectra.

\section{References}

1. $\quad \mathrm{Pu}, \mathrm{L}$. Asymmetric alkynylzinc additions to aldehydes and ketones. Tetrahedron 2003, 59, 9873-9886. 
2. Cozzi, P.G.; Hilgraf, R.; Zimmermann, N. Acetylenes in catalysis: Enantioselective additions to carbonyl groups and imines and applications beyond. Eur. J. Org. Chem. 2004, 4095-4105.

3. Qian, Y.; Zhang, H.J.; Lv, P.C.; Zhu, H.L. Synthesis, molecular modeling and biological evaluation of guanidine derivatives as novel antitubulin agents. Bioorg. Med. Chem. 2010, 18, 8218-8225.

4. Tu, H.Y.; Huang, A.M.; Hour, T.C.; Yang, S.C.; Pu, Y.S. Synthesis and biological evaluation of 2',5'-dimethoxychalcone derivatives as microtubule-targeted anticancer agents. Bioorg. Med. Chem. 2010, 18, 2089-2098.

5. Álvarez, C.; Corchete, P.; Pérez-Melero, C.; Peláez, R.; Menarde, M. Exploring the effect of 2,3,4-trimethoxy-phenyl moiety as a component of indolephenstatins. Eur. J. Med. Chem. 2010, $45,588-597$.

6. Mahesh, M.; Murphy, J.A.; LeStrat, F.; Wessel, H.P. Reduction of arenediazonium salts by tetrakis(dimethylamino)ethylene (TDAE): Efficient formation of products derived from aryl radicals. Beilstein J. Org. Chem. 2009, 5, doi:10.3762/bjoc.5.1.

7. Takechi, N.; Ait-Mohand, S.; Medebielle, M.; Dolbier, W.R., Jr. Nucleophilic trifluoromethylation of acyl chlorides using the trifluoromethyl iodide/TDAE reagent. Tetrahedron Lett. 2002, 43, 4317-4319.

8. Medebielle, M.; Dolbier, W.R., Jr. Nucleophilic difluoromethylation and trifluoromethylation using tetrakis(dimethylamino)ethylene (TDAE) reagent. J. Fluorine Chem. 2008, 129, 930-942.

9. Giuglio-Tonolo, G.; Terme, T.; Médebielle, M.; Vanelle, P. Original reaction of $p$-nitrobenzyl chloride with aldehydes using tetrakis(dimethylamino)ethylene (TDAE). Tetrahedron Lett. 2003, 44, 6433-6435.

10. Amiri-Attou, O; Terme, T.; Vanelle, P. Functionalization of 6-nitrobenzo[1,3]dioxole with carbonyl compounds via TDAE methodology. Molecules 2005, 10, 545-551.

11. Montana, M.; Terme, T.; Vanelle, P. Original synthesis of oxiranes via TDAE methodology: Reaction of 2,2-dibromomethylquinoxaline with aromatic aldehydes. Tetrahedron Lett. 2005, 46, 8373-8376.

12. Khoumeri, O.; Montana, M.; Terme, T.; Vanelle, P. First TDAE approach in quinonic series: Synthesis of new 2-substituted 1,4-dimethoxy-9,10-anthraquinones. Tetrahedron 2008, 64, 11237-11242.

13. Giuglio-Tonolo, G.; Terme, T.; Medebielle, M.; Vanelle, P. Nitrobenzylation of $\alpha$-carbonyl ester derivatives using TDAE approach. Tetrahedron Lett. 2004, 45, 5121-5124.

14. Montana, M.; Crozet, M.D.; Castera-Ducros, C.; Terme, T.; Vanelle, P. Rapid synthesis of new azaheterocyclic hydroxy-malonate derivatives using TDAE approach. Heterocycles 2008, 75, 925-932.

15. Juspin, T.; Laget, M.; Terme, T.; Azas, N.; Vanelle, P. TDAE-assisted synthesis of new imidazo[2,1-b]thiazole derivatives as anti-infectious agents. Eur. J. Med. Chem. 2010, 45, 840-845.

16. Amiri-Attou, O.; Terme, T.; Vanelle, P. Original and rapid access to new alkaloid analogues of neocryptolepine: Synthesis of substituted 6-methyl-6H-indolo[2,3-b]quinolines via TDAE strategy. Synlett 2005, 3047-3050.

17. Juspin, T.; Terme, P.; Vanelle, P. TDAE strategy using $\alpha$-diketones: Rapid access to 2,3-diphenylquinoline and acenaphtho[1,2-b]quinoline derivatives. Synlett 2009, 1485-1489.

18. Montana, M.; Terme, T.; Vanelle, P. TDAE-initiated synthesis of oxiranes in heterocyclic series: Reaction of 2-(dibromomethyl)quinoxaline with $\alpha$-dicarbonyl derivatives. Lett. Org. Chem. 2010, 7, 453-456. 
19. Khoumeri, O.; Giuglio-Tonolo, G.; Crozet, M.D.; Terme, T.; Vanelle, P. Original synthesis of 2-substituted-4,11-dimethoxy-1-(phenylsulfonyl)-2,3-dihydro-1 $H$-naphtho[2,3-f]indole-5,10-diones using TDAE and $\mathrm{Cu}$-catalyzed reaction strategy. Tetrahedron 2011, 67, 6173-6180.

20. Khoumeri, O.; Crozet, M.D.; Terme, T.; Vanelle, P. Original TDAE application: Synthesis of 2-substituted-4,11-dimethoxy-anthra[2,3- $b$ ]furan-5,10-diones via intramolecular Buchwald reaction. Tetrahedron Lett. 2009, 50, 6372-6376.

21. Dunn, L.A.; Tan, K.S.W.; Vanelle, P.; Juspin, T.; Crozet, M.D.; Terme, T.; Upcroft, P.; Upcroft, J.A. Development of metronidazole-resistant lines of Blastocystis sp. Parasitol. Res. 2012, 111, 441-450.

22. Roche, M.; Terme, T.; Vanelle, P. First Long-Distance $\mathrm{S}_{\mathrm{RN}} 1$ on a propargylic chloride Tetrahedron Lett. 2012, 53, 4184-4187.

23. Gellis, A.; Kovacic, H.; Boufatah, N.; Vanelle, P. Synthesis and cytotoxicity evaluation of some benzimidazole-4,7-diones as bioreductive anticancer agents. Eur. J. Med. Chem. 2008, 43, 1858-1864.

24. Delmas, F.; Gasquet, M.; Timon-David, P.; Madadi, N.; Vanelle, P.; Vaille, A.; Maldonado, J. Synthesis and in vitro anti-protozoan activity of new 5-nitrothiophene oxime ether derivatives. Eur. J. Med. Chem. 1993, 28, 23-27.

25. Boufatah, N.; Gellis, A.; Maldonado, J.; Vanelle, P. Efficient microwave-assisted synthesis of new sulfonylbenzimidazole-4,7-diones: Heterocyclic quinones with potential antitumor activity. Tetrahedron 2004, 60, 9131-9137.

26. Crozet, M.P.; Archaimbault, G.; Vanelle, P.; Nouguier, R. $\mathrm{S}_{\mathrm{RN}} 1$ Reactions in the heterocyclic series 4. Reactivity of 2,2-dimethyl-5-nitro-1,3-dioxane salts. Tetrahedron Lett. 1985, 26, 5133-5134.

27. El-Kashef, H.S.; El-Emary, T.I.; Gasquet, M.; Timon-David, P.; Maldonado, J.; Vanelle, P. New pyrazolo[3,4-b]pyrazines: Synthesis and biological activity. Pharmazie 2000, 55, 572-576.

28. Verhaeghe, P.; Azas, N.; Hutter, S.; Castera-Ducros, C.; Laget, M.; Dumetre, A.; Gasquet, M.; Reboul, J.-P.; Rault, S.; Rathelot, P.; et al. Synthesis and in vitro antiplasmodial evaluation of 4-anilino-2-trichloromethylquinazolines. Bioorg. Med. Chem. 2009, 17, 4313-4322.

29. Chinchilla, R.; Najera, C. The Sonogashira Reaction: A booming methodology in synthetic organic chemistry. Chem. Rev. 2007, 107, 874-922.

30. Since, M.; Terme, T.; Vanelle, P. Original TDAE strategy using $\alpha$-halocarbonyl derivatives. Tetrahedron 2009, 65, 6128-6134.

31. Price, C.C.; Carmelite, D.D. Reactions of epoxides in dimethyl sulfoxide catalyzed by potassium t-butoxide. J. Am. Chem. Soc. 1966, 88, 4039-4044.

32. Williams, D.H.; Flemming, I. Spectroscopic Problems in Organic Chemistry. In Spectroscopic Methods in Organic Chemistry, 4th ed.; Mc Graw-Hill: NewYork, NY, USA, 1991; pp. 76-101.

33. Montana, M.; Terme, T.; Vanelle, P. Original synthesis of alpha-chloroketones in azaheterocyclic series using TDAE approach. Tetrahedron Lett. 2006, 47, 6573-6576.

34. Nadji-Boukrouche, A.R.; Khoumeri, O.; Terme, T.; Liacha, M.; Vanelle, P. Original TDAE reactivity in benzoxa- and benzothiazolone series. ARKIVOC 2010, X, 358-370.

Sample Availability: Samples of the compounds $4 \mathbf{a}-\mathbf{g}, \mathbf{5 a}$ are available from the authors.

(C) 2013 by the authors, licensee MDPI, Basel, Switzerland. This article is an open access article distributed under the terms and conditions of the Creative Commons Attribution license (http://creativecommons.org/licenses/by/3.0/). 